\title{
電子レンジを用いた物質合成
}

\author{
加藤雅恒・榊原健二・小池洋二 \\ 東北大学大学院工学研究科応用物理学専攻 焉980-8579 宮城県仙台市青葉区荒巻字青葉 08 \\ (1999 年 5 月 10 日受理)
}

\section{Synthesis of Materials Using a Domestic Microwave Oven}

\author{
Masatsune Kato, Kenji SAKAKIBARA and Yoji KoIKe
}

Department of Applied Physics, Graduate School of Engineering, Tohoku University Aoba-yama 08, Aoba-ku, Sendai, Miyagi 980-8579

(Received May 10, 1999)

\begin{abstract}
Recently, much attention has been paid to the microwave processing in the preparation of inorganic materials. The advantages of microwave processing are uniformity of heat treatment and saving of energy and time, which are similar to those of microwave cooking. In this report, our recent research of the synthesis of High- $\mathrm{T}_{\mathrm{c}}$ superconductors using a domestic microwave oven is described. We have succeeded in obtaining single-phase samples of the Y-123, Bi-2201 and $\mathrm{Bi}-2212$ phases for several ten min without any post-heat-treatment using an electric furnace. In addition, several reports on the synthesis of other inorganic materials using a domestic microwave oven are introduced.
\end{abstract}

\section{1.はじめに}

火を使って物を著たり焼いたりして食べるということ は，大昔から今日までずっと行ってきた原始的な加熱調 理法である。しかし，現在では，電子レンジを使うこと により，短時間で簡単に調理することも可能になった。 電子レンジは, 第二次世界大戦中, ドイッのUボート の動きをキャッチするレーダー用に開発されたマイクロ 波技術を平和利用したもので，大戦後，米国で実用化さ れた。日本では 1961 年に初めて商品化され，1964 年に 新幹線のビュッフェに装備されて以来，スピード加熱が 評判になり, 今や普及率は全世帯の $90 \%$ に達し, 特に, 単身赴任のお父さんや親元離れた学生さん，最近の新米 奥様には生活必需品ともいえる。また, 寒い冬の夜など, 「レンジでチン!」すればあっという間に熱焩ができ上 がるのも大変有り難い。それはさておき, セラミックス などの無機材料の合成においては, 現在は電気炉を使っ て約 $1000-2000^{\circ} \mathrm{C}$ といら高温で数十時間加熱して試料 を得ているが, 家庭料理と同じく, 電子レンジを使えば 短時間で簡単に試料が得られ，試料合成プロセスの簡便 さ，低コスト，省エネルギーの点で実用化に役立つので はないかと思われる。実際, いわゆる電子レンジの原理 を用いたマイクロ波加熱は, 1980 年代初期に米国を中

E-mail: kato@teion.apph.tohoku.ac.jp
心に始まり ${ }^{1)}$, 近年, セラミックスの焼結や接合への応 用研究が盛んに行われてきている。電子レンジでは, 庫 内に多数のモードのマイクロ波が存在し，レンジ内で加 熱むらが生じるため, マグネトロンから発生された周波 数 $2.45 \mathrm{GHz}$ のマイクロ波を空洞共振器（キャビティー） 内の 1 か所に集中させるようなマイクロ波加熱装置も開 発されている2)。また，周波数 $28 \mathrm{GHz}$ のマイクロ波 ${ }^{3)}$ ミリ波 ${ }^{4)}$ を使った研究も行われている。我々は，より簡 便さを求め, 家庭用の電子レンジを用いて高温超伝導材 料のマイクロ波合成の研究を行ってきた（Fig. 1)。ここ では, まず, マイクロ波加熱の原理を簡単に述べ, 次に, 我々が行っている高温超伝導材料の合成方法, そして, 他の研究グループによる様々な物質の合成報告例を紹介 する。

\section{2. マイクロ波加熱の原理}

一般に，絶縁体に外から電場が加えられると分極が生 じる。分極には, Fig. 2 に示すように, 主に次の 3 種類 がある。電場が無くても存在する永久電気双極子モーメ ントが電場方向に配向することにより生じる配向分極, 電場がかかると, 正イオンと負イオンが互いに逆方向に 変位して生じるイオン分極, そして, 電場により電子雲 が原子核に対してわずかにずれることによって生じる電 子分極である。電場の周波数を上げていった場合，マイ クロ波領域ではイオン分極や電子分極は電場の変化に追 


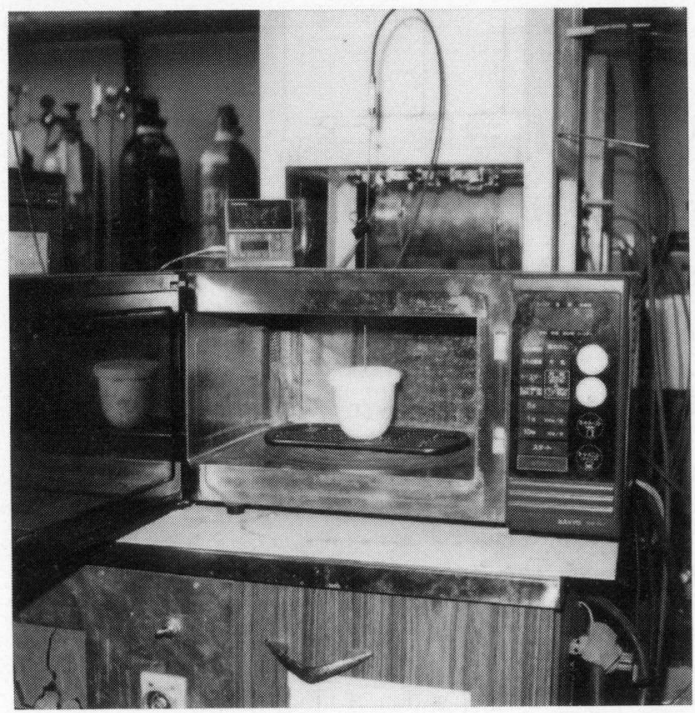

Fig. 1 View of the domestic microwave oven.

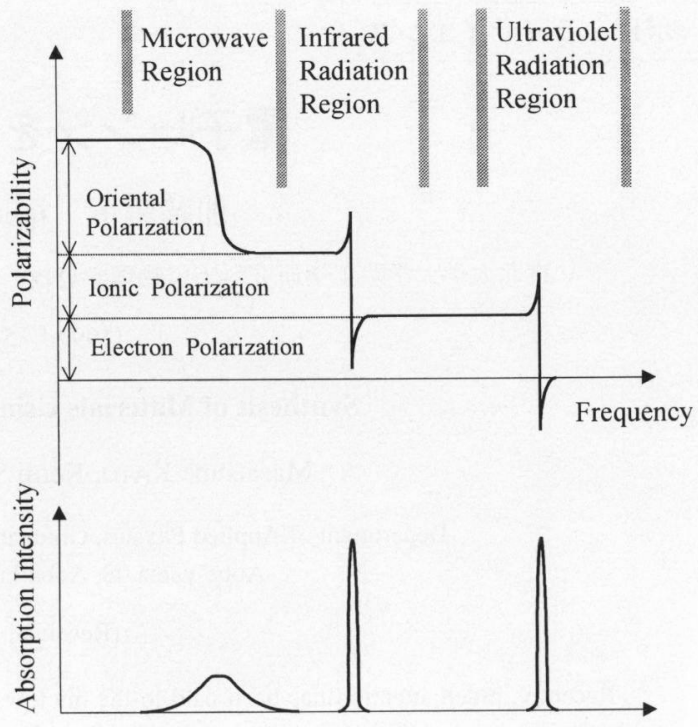

Frequency

Fig. 3 Dependences of the polarizability and absorption intensity on the frequency of electromagnetic wave.

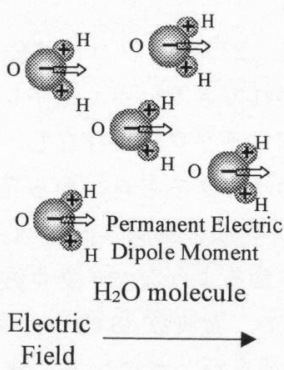

(a)

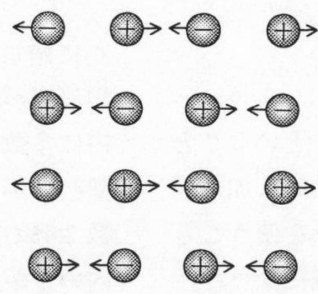

Electric Field

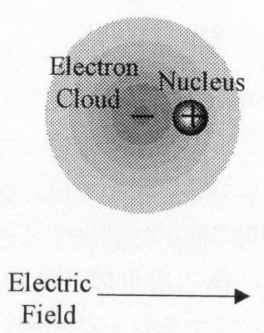

(c)

Fig. 2 Three kinds of polarization under electric field: (a) oriental polarization, (b) ionic polarization and (c) electron polarization.

いついていけるが，配向分極は液体中や固体中で分子が 向きを変えるために時間がかかるので電場の変化に真つ 先に追いついていけなくなる。この遅れのため発熱が起 こる。さらに周波数を上げると, 永久電気双極子モーメ ントはもう向きを変えようとしなくなるので発熱は起こ らなくなる。この限界の周波数は物質によって異なる。 したがって, $\mathrm{H}_{2} \mathrm{O}$ のように永久電気双極子をもち, 限界 の周波数が $2.45 \mathrm{GHz}$ 付近であれば, 家庭用の電子レン ジによって効率よく加熱されることになる。さらに周波 数を上げていくと, 赤外線領域で格子振動に関係するイ オン分極が電場の変化に追いつかなくなり, 紫外線領域 で電子分極が追いつかなくなる。この様子を Fig. 3 に示 す。これは，言ってみれば，車に乗って両側の店をウィ
ンドウ・ショッピングするのに似ている。車の速度が十 分遅いと首を左右に振ってウィンドウ・ショッピングで きるが, 速度が速くなると首がついていかなくなり, 最 後にはも5首を振らなくなる。結局, 首がついていける 限界の速度のところで一番疲れる（発熱する）。

それでは, $\mathrm{CuO}$ が電子レンジのマイクロ波を吸収す るのは配向分極によるのだろらか？しかし，ファンデア ワールスカで弱く結合した分子性結晶なら分子の反転も 考えられるが, イオン結晶のような場合には, たとえ永 久電気双極子を有していてむ反転することは無理のよう に思える。それゆえ, $\mathrm{CuO}$ がマイクロ波を吸収するの は配向分極によるのではないだろう。強誘電体は, ふつ らの格子振動の周波数（赤外線領域）に比べると格段に 
低い周波数をもち, その周波数が温度に敏感に変化する ような異常な格子振動のモード（ソフトモード）が存在 することが知られている。これは, イオンが対称性の高 い位置からわずかに变位することに起因する。 $\mathrm{CuO}$ は 強誘電体ではないが, このようなソフトモードが存在し, そのモードのイオン分極がマイクロ波領域で電場の変化 に追いつかなくなり, 発熱するのかもしれない。また, マイクロ波は電磁波であるため, 電場だけでなく磁場も 振動する。 $\mathrm{CuO}$ は約 $250 \mathrm{~K}$ 以下で反強磁性に転移する ことが知られており ${ }^{5)}, \mathrm{Cu}^{2+}$ スピン $(S=1 / 2)$ がマイク 口波領域での磁場の変化に追いつけなくなり, 発熱して いる可能性もある。しかし, 本当のところはよくわかっ ていない。

以上のように, マイクロ波を使った加熱法では, マイ クロ波を吸収する物質を一様に含む試料全体が内部から も一様に直接加熱されることになり, 短時間（数十分） の加熱で均質な焼結試料を得ることが可能になる。一方, 従来の電気炉による焼成では，まず電気炉が温められ， その後で高温の炉壁からの放射熱により試料表面がまず 加熱され, 熱伝導により内部が段々と高温になっていく 訳だから，均質な焼結試料を得るまでにかなりの時間を 要することになる。したがって, 電子レンジを用いれば かなりの短時間化, 省エネルギー化, 低コスト化が期待 できる。

\section{3. 高温超伝導材料の合成}

固相反応法による合成に電子レンジを利用するには, 少なくとも原料の 1 つが周波数 $2.45 \mathrm{GHz}$ という家庭用 電子レンジのマイクロ波を吸収しなければならない。と ころが, 高温超伝導体の原料には不可欠である $\mathrm{CuO}$ が 食材中の $\mathrm{H}_{2} \mathrm{O}$ と同じく $2.45 \mathrm{GHz}$ のマイクロ波を効率よ く吸収することが, 高温超伝導が発見された直後, Nature 誌に報告されている7。それによると，イギリスの Baghurst らは, 1-5 g の CuO に出力 $500 \mathrm{~W}$ のマクロ波 を照射すると, 1 分間で $550^{\circ} \mathrm{C}$ 以上にも加熱されるとの ことである。実際, この性質を利用して, 高温超伝導体 $\mathrm{La}_{2-x} \mathrm{Sr}_{x} \mathrm{CuO}_{4}$ と $\mathrm{YBa}_{2} \mathrm{Cu}_{3} \mathrm{O}_{7-x}$ の合成に応用している ${ }^{6,7)}$ 。

その後, $\mathrm{YBa}_{2} \mathrm{Cu}_{3} \mathrm{O}_{7-x}{ }^{8 \sim 10)}$ と $\mathrm{Tl}_{2} \mathrm{Ba}_{2} \mathrm{Ca}_{n-1} \mathrm{Cu}_{n} \mathrm{O}_{x}(n=2,3)^{11)}$ の合成についていくつか報告されている。しかしながら， いずれの場合も，何度も粉砕・混合・マイクロ波照射を 繰り返したり, マイクロ波照射後に電気炉を使って焼結 やアニールを行っている。これでは, せっかくの電子レ ンジの利点を活かしきっていない。その原因を次のよう に推測した。試料の温度は確かに $800-1000^{\circ} \mathrm{C}$ 近くまで 上がるが, 試料の周りの温度が室温であるため, 熱が試 料表面からどんどん逃げていってしまう。そのため, 試
料内が一様に加熱されているにもかかわらず, 試料内に 温度勾配ができ，不均質な試料になってしまったものと 思われる。また, マイクロ波照射が終了すると, 試料温 度は急激に下がるため, 特に, $\mathrm{YBa}_{2} \mathrm{Cu}_{3} \mathrm{O}_{7-x}$ においては 徐冷中に酸素を取り込むというプロセスが不十分にな り，マイクロ波照射だけでは超伝導性のよい試料を得る ことができなかったものと思われる。

そこで, 我々は試料表面からの熱リークを抑えるため, Fig. 4 に示すように, 混合し加圧成型したペレット状の 試料原料の周りをペレット状の試料原料と同じ組成の混 合粉末で覆い, さらにグラスウールで覆った。混合粉末 はペレット状の試料原料とグラスウールとの反応を防ぐ ために用いた。また，CuO を含む混合粉末自身も加熱 されるため, ペレットからの熱リークを抑えることにも 役立っている。この改良により, 我々は, 電気炉を使う ことなく, 電子レンジによるたった 1 回のマイクロ波照 射で Tc $90 \mathrm{~K}$ の高温超伝導体 $\mathrm{YBa}_{2} \mathrm{Cu}_{3} \mathrm{O}_{7-x}$ の合成に成 功した。以下にその合成法を具体的に紹介したい。

出発原料として, すべて酸化物粉末 $\mathrm{Y}_{2} \mathrm{O}_{3}, \mathrm{BaO}_{2}, \mathrm{CuO}$ を用いた。これらを全量 $15 \mathrm{~g}$ となるように秤量し, 十 分に混合する。そのうち $1 \mathrm{~g}$ を $7.6 \mathrm{kbar}$ の圧力で $10 \mathrm{~mm} \phi$ のペレット状に加圧成型する。次に, Fig. 4(A) に示 すように, $30 \mathrm{~cm}^{3}$ のアルミナ坩堝（日本化学陶業, SSAH B 1 型) の内側にグラスウール (東芝モノフラックス, ジュラブランケット 100）をしっかりと詰めたその中央 のスペース $(15 \mathrm{~mm} \phi \times 20 \mathrm{~mm})$ に, ペレット状の試料 原料を残りの原料混合粉末（14 g) で覆うようにして入

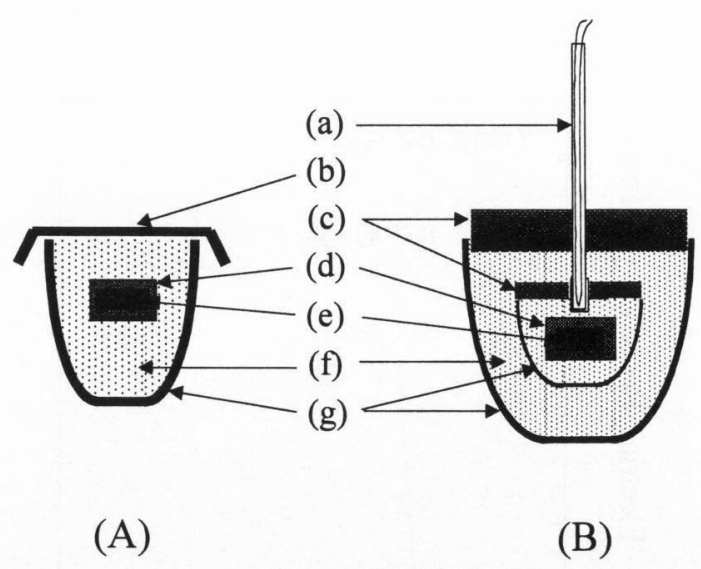

Fig. 4 Schematic diagrams of the sample environment in the case of $(\mathrm{A}) \mathrm{YBa}_{2} \mathrm{Cu}_{3} \mathrm{O}_{6.8}$ and (B) $\mathrm{Bi}_{1.6} \mathrm{~Pb}_{0.6} \mathrm{Sr}_{2} \mathrm{CaCu}_{2} \mathrm{O}_{x}$ : (a) sheathed thermocouple, (b) alumina cover, (c) firebricks, (d) mixed powder of the starting materials, (e) pellet of the mixed powder of the starting materials, (f) glass wool and (g) alumina crucibles. 
れる。その上にもグラスウールを詰め, さらに, アルミ ナ製の蓋をする。このアルミナ坩堝を家庭用電子レンジ （SANYO 社製，EMP-R 51 F）のターンテーブルの中央 に置いた。マイクロ波の出力 $(200 \mathrm{~W}, 350 \mathrm{~W} ， 500 \mathrm{~W})$ と照射時間を系統的に変化させて, 最良の烧結試料を得 るべく実験した。照射によりアルミナ坩堝もかなり高温 になるので, 室温に冷えてから取り出した。ペレットの 周りの粉末はサンドペーパーで軽く擦って取り除いた。

マイクロ波の出力が $350 \mathrm{~W}$ と $500 \mathrm{~W}$ の場合は, ペレ ットは 2 分以内で溶けてしまい, 焼結温度を照射時間で 制御することは難しかった。そこで，マイクロ波の出力 を最低の $200 \mathrm{~W}$ に固定して, 照射時間を变化させて合 成を試みた。その結果, 24 分以内の照射ではペレット はまったく反応しなかったが， 25 分間の照射でペレッ 卜も周りの粉末も黒くなり，よく焼結されたペレットが 得られた。このペレットを粉末 $\mathrm{X}$ 線回折で調べた結果,

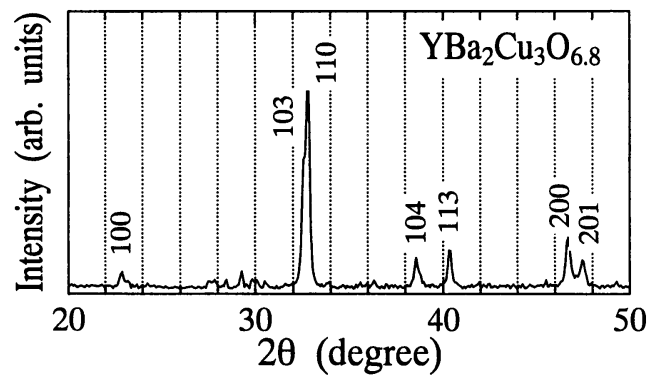

Fig. 5 Powder $\mathrm{X}$-ray diffraction pattern using $\mathrm{Cu} \mathrm{K} \alpha$ radiation for $\mathrm{YBa}_{2} \mathrm{Cu}_{3} \mathrm{O}_{6.8}$ obtained through radiation at $200 \mathrm{~W}$ for $25 \mathrm{~min}$.

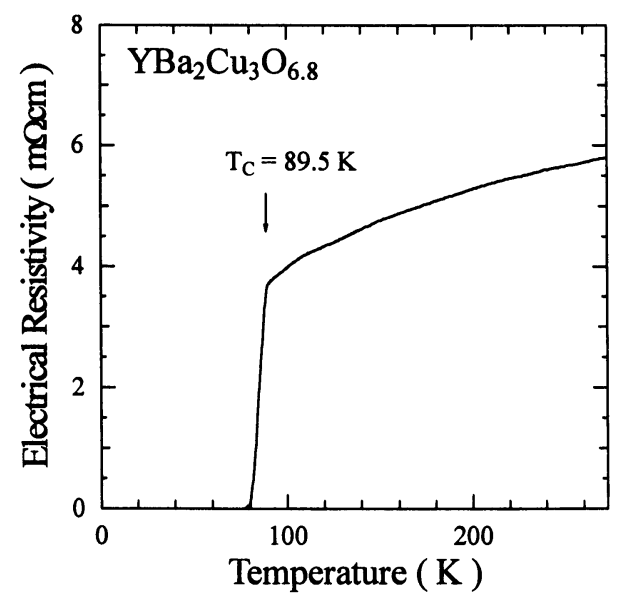

Fig. 6 Temperature dependence of the electrical resistivity for $\mathrm{YBa}_{2} \mathrm{Cu}_{3} \mathrm{O}_{6.8}$ obtained through radiation at $200 \mathrm{~W}$ for $25 \mathrm{~min}$.
ほぼ単相の $\mathrm{YBa}_{2} \mathrm{Cu}_{3} \mathrm{O}_{7-x}$ であることがわかった(Fig. 5)。 結晶構造は斜方晶で, 格子定数から見積もった酸素量 7- $x$ は 6.8 であった。この試料の電気抵抗率の温度依 存性を Fig. 6 に示す。一段で鋭い超伝導転移が観測され, Tc は $89.5 \mathrm{~K}$ であった ${ }^{12)}$ 。また, 26 分間の照射ではペレ ットは一部溶け始め, $\mathrm{Y}_{2} \mathrm{BaCuO}_{5}$ と $\mathrm{BaCuO}_{2}$ が現れた。27 分間の照射ではアルミナ坩堝がオレンジ色に光り始めた 途端，割れてしまった。試料は完全に融解していた。こ のように，わずか 1,2 分の間に急激に温度が上昇する ことがわかった。今回は 25 分間の照射で単相試料が得 られたが，照射時間は試料の量やマイクロ波の出力はも ちろん, アルミナ坩堝の大きさ, グラスウールの量や詰 め方, 使用する電子レンジによってもいくらか変わるの で，トライアンドェラーで決定するしかない。また，一 度融解してしまうと, 融液が広がって周りのグラスウー ルやアルミナ坩堝まで污染するので, 試料スペースに小 さいアルミナ坩堝をもう 1つ入れ, 融解してもこのアル ミナ坩堝のみ取り換えられるようにするとよい。

また，Bi 系高温超伝導材料については，Bi-2201 相は 同じ方法により, $\mathrm{Tc}=9.0 \mathrm{~K}$ の超伝導材料を得ることが できた ${ }^{13)}$ 。しかし，Bi-2212，Bi-2223 相については，す でに知られているように, 結晶が安定に育成される温度 領域が大变狭く, また, 結晶の育成に時間がかかるため, 高精度の温度制御や一定時間の温度保持が要求される。 そこで, Fig. 4 (B) に示すように, シース熱電対を使っ て試料近傍の温度をモニターし，手動で ON-OFFする ことにより温度制御を行った。その結果, 間に粉砕, 混 合, ペレット成型のプロセスを入れた 2 回のマイクロ波 照射により，単相のBi-2212 相を得ることに成功した $\left(\right.$ Fig. 7, 8) ${ }^{14)}$ 。

\section{4. 高温超伝導材料以外の合成}

我々は高温超伝導材料の合成しか行っていないが，そ の他の物質の合成もいくつか報告されているので紹介す る。高温超伝導材料と同じく $\mathrm{CuO}$ を含むセラミックス は当然合成できる。例えば，マイクロ波を吸収しない $\mathrm{Fe}_{2} \mathrm{O}_{3}$ とマイクロ波を吸収する $\mathrm{CuO}$ の混合粉末から， ス ピネル型 $\mathrm{CuFe}_{2} \mathrm{O}_{4}$ が 30 分間のマイクロ波照射で合成さ れたといら報告がなされている。通常の固相反応法の 23 時間に比べ，やはり大幅に短時間化できる6)。また，CuO 以外にも周波数 $2.45 \mathrm{GHz}$ のマイクロ波を吸収する酸化 物には, $\mathrm{ZnO}, \mathrm{V}_{2} \mathrm{O}_{5}, \mathrm{MnO}_{2}, \mathrm{PbO}_{2}, \mathrm{WO}_{3}$ 等がある6。

これを利用して, $\mathrm{KVO}_{3}$ は $\mathrm{K}_{2} \mathrm{CO}_{3}$ と $\mathrm{V}_{2} \mathrm{O}_{5}$ の混合粉末 からわずか 7 分で, $\mathrm{BaWO}_{4}$ は $\mathrm{BaO}$ と $\mathrm{WO}_{3}$ の混合粉末 から 30 分で合成できる。また, Validhyanathan ${ }^{15}$ は, 原料混合粉末に $\mathrm{Bi}_{2} \mathrm{O}_{3}, \mathrm{PbO}, \mathrm{V}_{2} \mathrm{O}_{5}$ を使い, 10-15 分の 


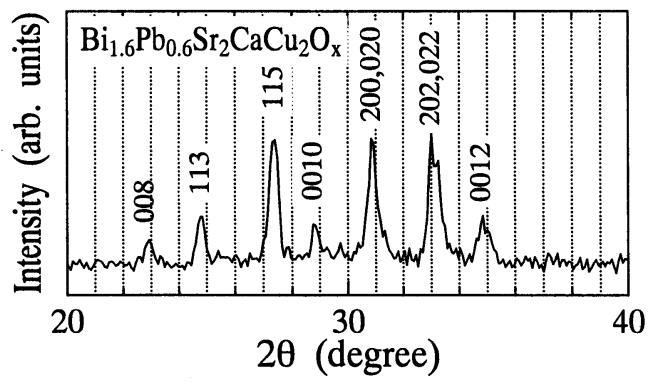

Fig. 7 Powder $\mathrm{X}$-ray diffraction pattern using $\mathrm{Cu} \mathrm{K} \alpha$ radiation for $\mathrm{Bi}_{1.6} \mathrm{~Pb}_{0.6} \mathrm{Sr}_{2} \mathrm{CaCu}_{2} \mathrm{O}_{x}$ obtained through the twice microwave-radiation process.

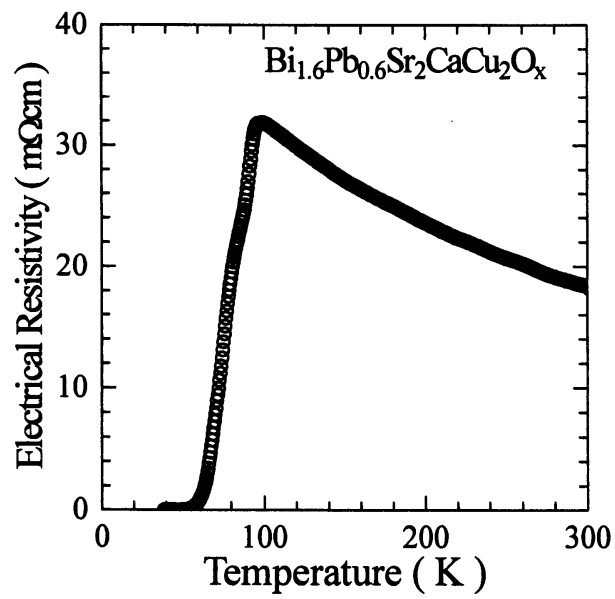

Fig. 8 Temperature dependence of the electrical resistivity for $\mathrm{Bi}_{1.6} \mathrm{~Pb}_{0.6} \mathrm{Sr}_{2} \mathrm{CaCu}_{2} \mathrm{O}_{x}$ obtained through the twice microwave-radiation process.

マイクロ波照射後， 2 時間の電気炉でのアニールを要す るが， $\mathrm{Bi}_{4} \mathrm{~V}_{2} \mathrm{O}_{11}, \mathrm{PbV}_{2} \mathrm{O}_{6}$ を得ている。また, 彼らは $\mathrm{Pb}$, $\mathrm{Zn}, \mathrm{Ag}$ 金属粉末とカルコゲン $(\mathrm{S}, \mathrm{Se}, \mathrm{Te})$ の混合粉 末を石英管に真空封入し，5-20 分のマイクロ波照射で $\mathrm{PbSe}, \mathrm{PbTe}, \mathrm{ZnS}, \mathrm{ZnSe}, \mathrm{AgS}$ の合成に成功している。 この合成はこれまでに述べてきた誘電加熱によるのでは なく, 伝導加熱, すなわち, 伝導電子が振動電場の影響 を受けて動いて交流電流を生じ，電気抵抗により発熱す ることによっている。その他に, Houmes ら ${ }^{16)}$ は混合金 属粉末を石英管に入れ，これを電子レンジに挿入し， $\mathrm{N}_{2}$ ガスを管内に流しながらマイクロ波を照射して，TiN， $\mathrm{AiN}, \mathrm{Li}_{3} \mathrm{Fe}_{2} \mathrm{~N}_{2}$ などの窒化物を短時間に合成している。 また，関口ら ${ }^{17)} は$ 電子レンジを使って，水素プラズマを 発生させ，酸化亜鉛を還元し紫外発光させることに成功 している。これらは，やはり誘電加熱以外の電子レンジ のおもしろい応用例である。

\section{5. よ め}

高温超伝導材料をはじめ様々な無機材料の電子レンジ を使ったマイクロ波合成の報告を紹介した。この合成法 は, 電気炉での合成法に比べて, 焼成時間を大幅に短縮 できるという特徴を持っている。マイクロ波合成は，始 まったばかりで研究報告例はまだ少なく, 内部加熱によ る急速加熱の効果以外にマイク口波による拡散促進等の 非加熱効果が存在するためであるかどうか，まだ明らか でない。今後, マイクロ波焼結機構解明とともに, 電気 炬では合成できない新物質がマイクロ波合成により可能 となることを期待する。

\section{謝 辞}

本研究の遂行に当たり, 東北大学大学院工学研究科の 滝澤博胤助教授, 疋田朋幸助教授, 東北大学学際科学研 究センターの粕谷厚生教授には貴重なアドバイスを頂 き, 大変感謝いたします。また, 本研究は, 文部省科学 研究費補助金, および, 科学技術振興事業団の戦略的基 礎研究推進事業 (CREST) の援助を受けて行われました。

\section{文献}

1) W.H. Sutton: Ceram. Bull. 68, 376 (1989).

2) 福島英沖 : セラミックス 32, 440 (1997).

3) T. Kimura, H. Takizawa, K. Uheda, T. Endo and M. Shimada: J. Am. Ceram. Soc. 81, 2961 (1998).

4) 三宅正司 : 粉体および粉末冶金 45, 1045 (1998).

5) B. Roden, E. Braun and A. Freimuth: Solid State Commun. 64, 1051 (1987).

6) D.R. Baghurst and D.M.P. Mingos: J. Chem. Soc. Chem. Commun. 829 (1988).

7) D.R. Baghurst, A.M. Chippindale and D.M.P. Mingos: Nature 332, 311 (1988).

8) K.G.K. Warrier, H.K. Varma, T.V. Mani and A.D. Damodaran: J. Am. Ceramic Soc. 75, 1990 (1992).

9) H.K. Varma, K.G. Warrier, V.A. Kumar, T.V. Mani, S.P. G.K. Pillai and A.D. Damodaran: Jpn. J. Appl. Phys. 31, L 543 (1992).

10) H. Feldstein, L. Ben-Dor and V. Beilin: Physica C 235240, 929 (1994).

11) S.S. Bayya and R.L. Snyder: Physica C 225, 83 (1994).

12) M. Kato, K. Sakakibara and Y. Koike: Jpn. J. Appl. Phys. 36, L 1291 (1997).

13) M. Kato, K. Sakakibara and Y. Koike: Appl. Superconductivity 5, 33 (1997).

14) M. Kato, K. Sakakibara and Y. Koike: Jpn. J. Appl. Phys. 38 (1999) in press.

15) B. Validhyanathan, M. Ganguli and K.J. Rao: Mater. Res. Bull. 30, 1173 (1995).

16) J.D. Houmes and H-C. Loye: J. Solid State. Chem. 130, 266 (1997)

17) 関口隆史 : 材料科学 35, 185 (1998). 